\title{
KOMUNIKASI INTERPERSONAL ORANG TUA DAN ANAK MENUJU KELUARGA TENANG DAN HARMONIS
}

\author{
Sun Fatayati*
}

\begin{abstract}
Abstrak
Communication is the main part of human life. Trough communication, people can express what they think and what they feel to some body else. They can also transmit message, persuade, negotiate and persuade other people. In marriage relationship communication plays an important role in maintaining a good relationship among members of the family especially husband and wife. A study reports that there were many couples aside having problem with their marriage due to their unability to build interpersonal communication between them. This paper argue's that in order to have a harmonious family, husband and wave need to built interpersonal communication shill.
\end{abstract}

Kata Kunci: Keluarga Harmonis, Komunikasi Interpersonal.

\section{Pendahuluan}

Berbicara tentang keluarga yang tenang dan harmonis, pastilah kita sepakat untuk mengambil ibrah dari kisah keluarga Ibrahim AS. Beliau dan istrinya Siti Hajar dan anaknya (Isma'il) di samping istri yang ke dua Siti Sarah dan anaknya (Ishaq), adalah contoh keluarga yang berhasil membangun kehidupan atas dasar keyakinan kepada Allah SWT.

Mereka dapat membangun idealisme dan cita-cita yang sangat tinggi disertai pengorbanan yang tanpa pamrih, kecuali mengharap ridho Allah semata. Betapa tidak. Ibrahim AS dinobatkan sebagai bapak tauhid sekaligus bapak para nabi karena kedua anaknya Ismail dan Ishak sebagai nabi yang

*Institut Agama Islam Tribakti (IAIT) Kediri 
kemudian melahirkan anak-anak cucu yang juga menjadi nabi. Dari Ishak terlahir nabi-nabi di kalangan bani Israil, seperti Yaqub, Yunus, Harun, Musa, Isa dan seterusn. Adapun dari nabi Ismail terlahir nabi mutaahir yaitu nabi Muhammad SAW. Sukses keluarga para nabi tersebut, juga tidak bisa dipisahkan dari peran ibu yang hebat, ayah yang bijak dan anak yang slaleh dan słalehah serta peran komunikasi diantara anggota keluarga yang baik secara inten.

Berbeda dengan fenomena yang terjadi fenomena yang terjadi saat ini, banyak keluarga yang bercerai berai dan saling menyakiti, saling menuntut. Hal ini menimbulkan keprihatinan keluarga yang seharusnya menjadi sumber kasih sayang, sumber kebahagiaan, sudah tidak mampu memberikan kasih sayang dan kebagiaan, sudah tidak mampu memenuhi nafkah batin anak serta memberi perlindungan pada anak, bahkan menjadi tempat yang hampa dan menyakitkan..

Beberapa berita yang muncul di berbagai media bahwa akar permasalahan utama yang menjadi penyebab mengapa keluarga tersebut hancur adalah ketiadaan komunikasi antar pribadi yang baik pada pasangan tersebut (tidak memiliki keterampilan komunikasi yang baik) sehingga muncul berbagai permasalahan yang tidak berhasil diselesaikan dengan hasil yang sama-sama memuaskan akal semua pihak. Pada hal keluarga merupakan lingkungan sosial terkecil dari kehidupan manusia. Ada yang mengatakan bahwa keluarga juga disebut fondasi sosial pertama bagi manusia. Ada juga yang mengatakan bahwa keluarga merupakan ukuran utama kehidupan sosial seseorang.

Kesuksesan seseorang di bidang apapun tidak bisa dikatakan murni atas usahanya sendiri, sementara mengabaikan sisi lain dibalik kesuksesannya yakni dukungan keluarga (orang tua, istri, suami dan anak-anak). Keluarga sukses menurut hemat penulis, bukan dilihat dari ukuran kekayaan finansial yang dimiliki atau strata sosial yang mampu dicapai oleh seseorang, akan tetapi lebih pada kemampuan keluarga tersebut memerankan fungsinya sebagai fondasi sosial terkecil dalam melahirkan generasi penerus yang sukses pula.

Untuk tujuan tersebut, paling tidak memuat dua pengertian keluarga sukses, tenang dan harmonis adalah: 
1. Keluarga yang mampu menghadapi masalah-masalah kehidupan, baik ketika dipuncak kejayaan maupun saat-saat turun terpuruk di dasar kegagalan, lengkap dengan konsekuensi sosial dan finansialnya.

2. Keluarga tersebut haruslah terdiri dari Bapak dan Ibu yang piawai dan berkemampuan dalam melahirkan generasi penerus yang sukses yaitu yang berkemampuan untuk mandiri secara finansial maupun mandiri secara sosial sekaligus mampu menghadapi masala-masalah yang terjadi pada zamannya.

\section{Hakikat Keluarga Tenang Dan Harmonis}

Dalam QS Ash Shafat (37) ; 99-102

Dan Ibrahim berkata:"Sesungguhnya aku pergi menghadap kepada Tuhanku, dan Dia akan memberi petunjuk kepadaku. Ya Tuhanku, anugrahkanlah kepadaku (seorang anak) yang Termasuk orang-orang yang saleh.. Maka Kami beri Dia khabar gembira dengan seorang anak yang Amat sabar. Maka tatkala anak itu sampai (pada umur sanggup) berusaha bersama-sama Ibrahim, Ibrahim berkata: "Hai anakku Sesungguhnya aku melihat dalam mimpi bahwa aku menyembelihmu. Maka fikirkanlah apa pendapatmu!" ia menjawab: "Hai bapakku, kerjakanlah apa yang diperintahkan kepadamu; insya Allah kamu akan mendapatiku Termasuk orang-orang yang sabar".

Keluarga adalah suatu lembaga yang terdiri dari dua orang atau lebih yang saling komitmen dan berbagi kehangatan, sumber daya, keputusan dan nilai-nilai. ${ }^{1}$ Menurut Nich keluarga kokoh menjadikan keluarga memiliki kondisi keluarga yang kokoh menjadi pilar bagi terbentuknya keluarga yang harmonis. ${ }^{2}$

\footnotetext{
${ }^{1}$ Nich, dkk, Fantastic Families (keluarga Kokoh dan bahagia), (Batam: Iteraksara, 2001), h. 21.

${ }^{2}$ Ibid., h. 34.
} 
Menurut Misbahul Huda ada lima pilar yang yang dibangun untuk mencapai keluarga tenang dan harmonis:

1. Memiliki visi dan misi yang jelas. Seluruh anggota keluarga berdiskusi dalam menghasilkan kesejahteraan, kebahagiaan di antara mereka, saling menjaga, memelihara dalam ketaatan kepada Allah SWT. Nabi Ibrahim sebagai seorang ayah, pemimpin keluarga yang juga Nabi pergi berdakwah keberbagai pelosok untuk menyebarkan risalah Allah SWT, Siti Hajar sang istri, dengan ikhlas mendukung kegiatan ini sekaligus memberikan dorongan dan doa agar suaminya mendapatkan keberkahan dari Allah SWT.

2. Membangun keyakinan terhadap turunnya pertolongan Allah SWT yang dilandasi dengan kegigihan berusaha dan berikhtiar. Sebagai contoh, kerelaan Siti Hajar bersama bayi Ismail di padang tandus Mekkah dipisahkan dengan istri tuanya Siti Sarah. Juga kegigihan Hajar ketika mencari air untuk memenuhi kebutuhan anaknya yang masih kecil (Ismail). Sang ibu berlari-lari kecil antara bukit Shafa dan bukit Marwah. Dengan izin-Nya akhirnya keluarlah mata air yang tak pernah diduga sebelumnya, yaitu air zam-zam.

3. Membudayakan diskusi dan musyawarah antara sesama anggota keluarga, sehingga timbul pemahaman dan pengertian yang baik antara satu dengan yang lain dalam keluarga. Sebagai contoh ketika Ibrahim As. bermimpi untuk menyembelih anaknya (yang diyakini sebagai perintah Allah SWT). Dalam implementasinya tetap berdialog dengan anaknya. Lalu keduanya melaksanakan ketentuan Allah SWT dengan penuh kesadaran dan keikhlasan.

4. Selalu berdoa, memohon kepada Allah SWT agar mendapatkan anak dan keturunan yang słaleh dan słalehah, sebagai pewaris dan penerus perjuangan orang tuanya. Tentu anak diharapkan juga mampu mendirikan s\{alat dengan sebaik-baiknya. 
5. Membangun semangat berkorban untuk menumbuhkan kecintaan kepada Allah SWT dan kecintaan kepada sesama manusia. $^{3}$

Adapun menurut Nick (2001) terdapat 6 sifat keluarga yang harmonis.

1. Mempertahankan dan menyebarkan komitmen. Anggota keluarga berdedikasi dalam mengingkatkan kesejahteraan dan meningkatkan kebahagiaan di antara anggota keluarga.

2. Penghargaan dan kasih sayang angota keluarga harus menunjukkan saling menghargai, saling menyayangi serta saling membutuhkan antara satu dengan yang lain, agar mereka dapat merasakan, betapa berartinya dan baiknya sebuah keluarga.

3. Komunikasi yang positif, menyediakan cukup waktu, mendengarkan menyelami dunia pasangan, pertahankan kejujuran anggota keluarga harus memiliki keterampilan dalam berkomunikasi, menyediakan waktu untuk berinteraksi, banyak mendengarkan dan memahami dunia mereka (suami, istri dan anak-anak) serta mempertahankan dan membudayakan kejujuran di antara mereka.

4. Waktu bersama kualitas dan kuantitasnya. Keluarga harus menghabiskan waktu, baik kwantitas maupun kwalitas dalam keluarga.

5. Kesejahteraan spiritual. Seluruh anggota keluarga hendaknya memiliki kepercayaan dan perasaan tentangadanya kekuasaan yang lebih besar (Tuhan) dalam hidup. Ini sangat penting dan sangat berarti dalam keharmonisan keluarga, keyakinan tersebut untuk dijadikan pedoman dalam segala hal.

6. Kemampuan mengatasi stress. Keluarga tenang dan harmonis, harus dapat mengatasi krisis dan stres secara bersama-sama. Misal dalam keluarga terjadi krisis, maka seluruh anggota keluarga bersama sama mencari jalan keluar dari krisis tersebut, demikian pula apabila dalam keluarga ada yang mengalami stres, maka perlu dicari jalan

${ }^{3}$ Misbahul Huda, Keluarga Harmonis (Surabaya: Ummi Inside, 2011), h. 5 
keluar dan dibicarakan dengan tenang, untuk saling menguatkan, memberi dukungan dan motivasi. ${ }^{4}$

Firman Allah dalam Surat Yunus (10:87): "Dan Kami wahyukan kepada Musa dan saudaranya, ambillah olehmu berdua beberapa rumah di Mesir untuk tempat tinggal bagi kaummu dan jadikanlah olehmu rumah-rumahmu itu sebagai kiblat dan dirikanlah sholat serta gembirakanlah orang-orang yang beriman"

Ada empat hal yang menjadi perhatian kita, yakni: Pertama, menjadikan rumah sebagi kiblat. Kedua menjadikan rumah sebagai masjid. Ketiga menjadikan rumah sebagai tempat slalat. Keempat rumah sebagai tempat mebaca Al-Qur'an. Kelima Rumah tempat berzlikir. Keenam rumah sebagai majelis ilmu.

\section{a. Rumah sebagai kiblat.}

Kiblat kalau boleh dibahasakan adalah mercusuar, maksudnya, bahwa rumah merupakan mercusuar atau panduan bagi kehidupan seseorang ketika keluar rumah. Artinya rumah merupakan lingkungan pertama pembentukan watak dan perilaku penghuninya. Manakala dalam pembentukan pertama bagus maka akan terlahir generasi dengan perilaku yang berkarakter. Begitu pula manakala pembentukan di rumah buruk maka perilaku yang terlahir dan terbawa di rumah tangga juga buruk. Sabda Ali r.a: "didiklah anak-anakmu karena mereka akan memasuki zaman yang bukan zamannya lagi”.

\section{b. Rumah sebagai masjid}

Hadits nabi Muhammad SAW, "perumpamaan rumah yang selalu disebut nama Allah disitu dengan rumah yang tidak pernah disebut nama Allah (disitu) adalah seperti orang hidup dan orang mati”. (Bukhori-Muslim). Rumah sebagai masjid adalah dengan mengkondisikan rumah sebagaimana kita bersikap dan bertindak terhadap masjid. Masjid sebagai pusat ilmu sebagai tempat mendekatkan diri kepada Allah dan juga tempat pembinaan rukyah maupun jasadiyah bagi setiap muslim. Di dalam masjid kita beribadah kepada Allah dan di dalam

\footnotetext{
${ }^{4}$ Nich, dkk, Fantastic Families, h. 23
} 
masjid kita juga berinteraksi dengan saudara-saudara kita dengan baik. Kita jaga lidah, amarah dan tingkah laku.

Demikian pula semestinya keadaan di rumah kita, jika kita benar-benar memahami hakikat dan fungsi rumah sebagai masjid maka kita jaga lidah kita terhadap anggota keluarga. Kita lembutkan suara, kita tingkatkan ketaqwaan dan nuansa taqarrub ilaallah.

\section{c. Rumah sebagai tempat s\{alat}

$\mathrm{S}\{$ alat merupakan ibadah mulia dan agung dalam Islam. Ia harus diperhatikan oleh setiap muslim. Hendaklah seorang muslim tidak mengharamkan rumahnya dari kebaikan dan keberkahan ibadah yang agung ini. Caranya yaitu dengan melaksanakan $\mathrm{s}\{$ alat di rumah. Melaksanakan $\mathrm{s}\{$ alat bagi perempuan (istri dan anak-anak perempuan) adalah jelas karena rumah adalah tempat terbaik bagi mereka. Bagi laki-laki (suami dan anak laki-laki) adalah dengan melaksanakan s alat sunnah di dalamnya, karena untuk s $\{$ alat wajib bagi laki-laki tempatnya di masjid.

Memang tidak mudah menegakkan salat di rumah apalagi harus berjama'ah dengan anak istri, harus tepat waktu dan dilaksanakan dengan istiqomah. Namun ada cara paling sederhana dan praktis yaitu sebisa mungkin mengajak anggota keluarga untuk bersama-sama salat berjama'ah. Dengan cara sederhana itu banyak hal yang bisa terjaga, tertib tata cara (kaifiyah), tertib waktu, terjaga wudhunya, bacaannya dan gerakan-gerakan salatnya.

\section{d. Rumah sebagai tempat membaca Al-Qur'an}

Membaca Al-Qur'an secara umum diperintahkan termasuk membacanya di dalam rumah, karena bacaan AlQur'an di rumah menghadirkan keberkahan. Membiasakan anggota keluarga untuk membaca Al-Qur'an adalah wajib. Demikian juga isi Al-Qur'an bisa dijadikan suri tauladan dan mauidhoh hasanah bagi seluruh anggota keluarga.

\section{e. Rumah sebagai tempat berzlikir}

Sabda Rasulullah SAW, "berzikirlah di rumahmu supaya rumahmu tidak menjadi kuburan, disamping kuburan adalah 
tempat orang mati dan rumah yang tidak ada dzikir kepada Allah didalamnya dalah mati" (HR.Muslim). Dari hadis tersebut, seorang muslim harus menjadikan rumahnya sebagai tempat mengingat Allah, baik zikir hati maupun zikir lisan.

\section{f. Rumah sebagai majelis ilmu}

Jauh sebelum ada sekolah atau madrasah maka sesungguhnya rumah sebagai basis pendidikan. Salah satu bentuk tanggungjawab pemimpin rumah tanggga adalah menanamkan dan mengajarkan nilai-nilai Islam pada anggota keluarganya agar mereka mengamalkannya dengan dasar ilmu yang benar. Hal ini salah satunya dengan mengadakan majelis ilmu di rumah secara periodik.

\section{Hakikat Komunikasi Dalam Keluarga.}

Untuk membangun keluarga yang tenang dan harmonis ada beberapa syarat, di antaranya adalah adanya komunikasi interpersonal antara pasangan dan anak-anak. Terutama suami dan istri, karena suami dan istri adalah nahkoda keluarga yang akan mengarahkan dan membawa keluarga mewujudkan fungsi dan perannya di tengah masyarakat.

Komunikasi adalah setiap bentuk tingkah laku seseorang, baik verbal maupun nonverbal yang ditanggapi oleh orang lain. Komunikasi mencakup pengertian yang lebih luas dari sekedar wawancara. Setiap bentuk tingkah laku mengungkapkan pesan tertentu, sehingga merupakan sebentuk komunikasi.

Secara umum komunikasi diartikan sebagai pesan yang dikemukakan seseorang kepada satu atau lebih penerima dengan maksud sadar untuk mempengaruhi tingkah laku si penerima. Dalam setiap bentuk komunikasi setidaknya terlibat dua orang yang saling mengirimkan lambang-lambang yang memiliki makna tertentu. Lambang-lambang tersebut bisa bersifat verbal berupa kata atau bersifat nonverbal berupa ekspresi atau ungkapan tertentu atau berupa isyarat-isyarat dan gerak tubuh atau gambar-gambar.

Sedangkan yang dimaksud suami istri yaitu dua orang yang dipersatukan oleh janji perkawinan dan keduanya menjadi terikat satu sama lain, baik secara fisik maupun secara emosional, dan keterikatan cinta merupakan kesatuan jiwa raga, 
pikiran, perasaan, kemauan, kehendak dan bahkan cinta kasih dan citra rasa di antara mereka. Mereka berjanji untuk hidup bersama dalam membangun keluarga yang didasarkan cinta kasih dan melaksanakan perintah Tuhan di dalam kehidupan keluarga. ${ }^{5}$

Keluarga yang sah dibangun lewat perkawinan yang syah, perlu terus menerus dipertahankan, dilestarikan dan sejauh mungkin diabadikan dengan berbagai upaya keras dan perjuangan yang gigih. Kuncinya terletak pada kemahiran mereka dalam keluarga untuk berkomunikasi interpersonal yang baik. Haat berpendapat bahwa komunikasi adalah kunci untuk memecahkan perselisihan dan jalan satu-satunya untuk berkeluarga bersama. ${ }^{6}$

Komunikasi interpersonal berlangsung antara individu, bersifat pribadi dan di bangun di atas sendi-sendi pengakuan dan penghargaan yang tinggi atas martabat manusia. Maka komunikasi interpersonal (kerap disebut juga komunikasi antar pribadi) mampu memanusiakan manusia sebagai pribadi yang pantas dan selayaknya dihormati dan dihargai, diperdayakan baik posisinya sebagai orang tua maupun sebagai anak. De Vito menyatakan bahwa karena sifatnya yang interpersonal inilah, maka komunikasi antar pribadi mampu menjadi salah satu unsur paling penting dalam membentuk pribadi, menggerakkan partisipasi, memodifikasi sikap prilaku individu dan bahkan ampuh dalam mengatasi konflik dan kepentingan. ${ }^{7}$

Komunikasi interpersonal dalam keluarga merupakan hubungan sehingga kelebihan yang didapatkan feet back di peroleh segera oleh setiap anggota keluarga yang terlibat dalam pembicaraan. Komunikator akan segera menyesuaikan diri dengan situasi dari pasangan bicaranya. Dengan demikian melalui penyesuaian diri akan ada arus balik yang positif.

\footnotetext{
${ }^{5}$ Wright, Komunikasi Kunci Pernikahan Bahagia, (Yogyakarta, Yayasan Gloria, 1997), h. 55.

${ }^{6}$ Thomas Hunt \& Karlheen, Dua Tahun Pertama Hidup Berkeluarga, (Yogyakarta: Kanisius, 1988), h. 17.

${ }^{7}$ De Vito, JA., Komunikasi Antar Pribadi, (Jakarta: Prof Book. 1997), h. 23.
} 
Oleh karena perlunya strategi dan perencanaan komuikasi untuk mengidentifikasi isi pesan dengan susunan sebagai berikut:

a. Pesan harus di rancang dan disampaikan sedemikian rupa, sehingga dapat menarik perhatian komunikan.

b. Pesan harus menggunakan lambang dan tertuju pada pengalaman yang sama antara komunikator dan komunikan sehingga sama-sama mengerti.

c. Pesan harus membangkitkan kebutuan pribadi komunikan dan menggunakan beberapa cara untuk mengambil kebutuhan tersebut.

d. Pesan harus menyesuaikan suatu untuk memperoleh kebutuhan yang banyak.

\section{Ciri dan Fungsi Komunikasi Interpersonal Orang Tua dan Anak}

Komunikasi interpersonal antar orang tua dan anak terjadi melalui tatap muka sehingga memberikan suatu keuntungan dimana keduanya terlibat dalam prilaku nonverbal, ekspresi facial, kedekatan jarak fisik, prilaku paralinguistik, yang dapat mempermudah jarak sosial dan menumbuhkan kedekatan. Abraham Maslaw, komunikasi interpersonal sebagai kebutuhan akan cinta. Dalam hal ini suami dan istri (dan juga anak) sama-sama saling menghargai dan dihargai sebagai bagian cinta dan perhatian. Kekuatan 'cinta' inilah yang mampu menggerakkan spirit pengabdian, loyalitas yang lebih sejati dalam membangun keluarga yang harmonis.

Riardon bahwa komunikaasi interpersonal mempunyai enam ciri, yakni:

a. Dilaksanakan karena berbagai faktor

b. Berakibat sesuatu yang disengaja atau tak disengaja.

c. Kerap kali berbalas-balasan.

d. Mengisyaratkan adanya hubungan (paling sedikit 2 orang antar pribadi)

e. Menggunakan berbagai lambang yang bermakna.

Adapun fungsi komunikasi interpersonal, Hafid Cangata mengemukakan ada beberapa fungsi:

a. Untuk menyehatkan hubungan insani (human relation)

b. Mengatasi konflik pribadi. 
c. Mengurangi ketidakpastian sesuatu.

d. Berbagai pengetahuan dan pengalaman dengan orang lain.

Dalam penetapannya pada kehidupan bersama, komunikasi interpersonal dapat menumbuhkan hubungan kemanusiaan di antara para pihak yang melakukan komunikasi. Dan mereka dapat memperoleh kemudahan dalam hidupnya, untuk saling membina hubungan yang baik, sehingga memungkinkan untuk menghindari dan mengatasi adanya konflik..

Komunikasi interpersonal sangat memungkinkan terjadinya pengembangan hubungan antara komunikator dan komunikan. Meskipun interpersonal tersebut dapat disebabkan karena;

a. Alasan untuk membina hubungan telah luntur. Bila pengenalan diri dan pertumbuhan diri tidak lagi memadai kita menjadi tidak puas, baik terhadap diri kita sendiri dengan mitra dan dengan hubungan itu sendiri.

b. Hubungan pihak ketiga. Bila suatu hubungan yang baru dapat memenuhi kebutuhan secara lebih baik, hubungan yang lama bisa manjadi rusak.

c. Perubahan sifat hubungan. Perubahan sifat hubungan secara psikologis, perilaku dan status pada salah satu atau kedua pihak dapat mendorong rusaknya kedua hubungan.

d. Harapan yang tak terkatakan. Konflik yang tak terselesaikan akan menimbulkan kekecewaan dan melunturkan perasaan yang dulunya ada.

e. Komitmen. Berkurangnya komitmen, waktu, keuangan dan emosional.

Untuk mengatasi hambatan tersebut, de Fitto menyarankan ada 5 kualitas umum yang perlu diciptakan untuk memelihara keberlangsungan komunikasi interpersonal antara orangtua dan anak, antara suami dan istri, yaitu: Keterbukaan (openis); Empati (empathy); Dukungan (supportiveness); Rasa positif (positivisness); Kesamaan (equality).

Sedangkan Allyn dan Bacon, hambatan komunikasi interpersonal dapat terjadi dengan cara: pertama, Legitimasi, Dalam hubungan interpersonal kedudukan seseorang dapat menghambat komunikasi yang digunakan. Kedua, Perbedaan pandangan, Perbedaan pandangan dapat mempersulit proses 
pengungkapan diri orang lain. Ketiga, Kurangnya suatu pengetahuan atau pengalaman, Tingkat pengetahuan yang berbeda dapat menimbulkan kontroversi dalam menggapai pesan yang disampaikan. Keempat, Paksaan, Tekanan, ancaman dan paksaan atau saknsi/ hukuman akan memberi pengaruh negatif terhadap komunikan. Kelima, Kegunaan, Kekurang manfaatan pesan yang disampaikan komunikator untuk memenuhi apa yang dibutuhkan komunikan dapat membuat komunikasi interpersonal tidak bermakna.

Komunikasi adalah bagian inti dari kehidupan manusia. Melalui proses komunikasi seseorang berusaha untuk menyampaikan pikiran dan perasaannya kepada orang lain. Dari proses komunikasi tersebut tercipta upaya dalam mempengaruhi orang lain untuk ikut merasakan atau lebih jauh melakukan apa yang dikehendaki oleh komunikator, sehingga terjalin saling memahami antara komunikator dan komunikan. Ini sangat penting hubungan dalam suatu rumah tangga, baik antara suami istri dan orang tua serta anak-anaknya.

\section{Kesimpulan}

Komunikasi interpersonal dalam keluarga adalah salah satu kunci utama untuk membangun keluarga yang tenang dan harmonis. Keluarga yang tenang dan harmonis adalah dambaan setiap insan, oleh karena itu diperlukan kerja sama seluruh anggota keluarga baik orang tua maupun anak-anak. Agar komunikasi bisa menghasilkan hubungan interpersonal yang efektif, kerja sama bisa ditingkatkan, baik perlu bersikap terbuka dan menggantikan sikap dogwats. Kita perlu memiliki sikap percaya dan mendukung, terbuka yang mendorong timbulnya sikap saling memahami dan menghargai sesama anggota keluarga, dan yang tidak kalah pentingnya adalah adanya selalu positif thinking dan berkata jujur. Dengan demikian semua menjadi 'enak' dan tidak menjadi beban.

\section{Daftar Pustaka}

Al Quran dan Terjemahnya, Depag RI

Hunt, Thomas \& Karlheen, Dua Tahun Pertama Hidup Berkeluarga, Yogyakarta, Kanisius, 1988. 
Lilineri, Alo, Komunikasi antar Pribadi, Bandung, Citra Aditya Bakti, 1991.

Misbahul Huda, Ummi Inside, Surabaya, 2011.

Nich, dkk, Fantastic Families (keluarga Kokoh dan bahagia), Batam, Iteraksara, 2001.

Supratikknya, A. Komunikasi antar Pribadi, Yogyakarta, Kanisius. 1995

Vito, JA. De, Komunikasi Antar Pribadi, Jakarta, Prof Book. 1997.

Wright, Komunikasi Kunci Pernikahan Bahagia, Yogyakarta, Yayasan Gloria, 1997. 